\title{
CORRESPONDENCE.
}

\section{Pedro Teixeira.}

DeAR Sir,-Mr. W. F. Sinclair's letter appearing on pp. 624-628 of the July number of the R.A.S. Journal appeals for information about Teixeira.

First, as to Pedro Teixeira's book. There are four copies of the original edition of 1610 in the British Museum Library, one being in the Grenville collection. Of the three former, one has been copiously annotated by its previous (scholarly) owner. There is also a copy of the French translation of 1681 (1621 is a misprint in the "Biographie Universelle"). The British Museum Library, moreover, contains several copies of the English translation, by Captain John Stevens, of Teixeira's Voyage from India to Italy, published in 1710 (P) in vol. ii of "A New Collection of Voyages and Travels" (reissued in 1711 with new title-pages and a dedication by Stevens). It has also a copy of Stevens's translation of the History of Persia, published separately in 1715. (In this last, Teixeira's first name is erroneously given on the title-page as "Anthony.") I have compared Stevens's translations somewhat cursorily with the originals; and they appear to be, on the whole, faithful versions, though in many places strange words and proper names are misprinted or transformed. It is curious that Sir Henry Yule did not enter Teixeira's name in the index to his "Book of Ser Marco Polo." In the list of authorities at the end of vol. ii, however, he gives the full title of Teixeira's book, but with the misprinted date 1619 . 
He also enters it in the list of works at the beginning of "Hobson-Jobson," and quotes from it in the body of this book. It is remarkable that he makes no mention of Stevens's translations, though he could hardly have been ignorant of them. ${ }^{1}$

As regards the man, little seems to be known of him beyond what is to be gathered or inferred from his book. To J. J. Benjamin's "Eight Years in Asia and Africa” (1863) is prefixed a biographical notice of Pedro Teixeira by Dr. M. Kayserling, but it does not add much to our knowledge of the traveller. The most important fact that Dr. Kayserling gives us is, that Pedro Teixeira was a Jew, or, rather, of Jewish parentage (born probably in Lisbon) ${ }^{2}$; for Dr. Kayserling infers " from his narrative that during a great part of his life-during his travels-that preceded his arrival in Antwerp he was a Christian, and was a devout Catholic." Dr. Kayserling adds:-“It was at Antwerp, the oldest Dutch settlement of the Spanish-Portuguese exiles, that Pedro took up his abode after the termination of his journey. There he published his valuable work on the origin and order of succession of the kings of Persia and Harmez; there he wrote his 'Travels from India to Italy'; and there, not at Verona, most probably towards the middle of the seventeenth century, he died in the Jewish faith, and was gathered to his fathers in a better world." In a footuote Dr. Kayserling mentions several writers who give Verona as the place where Teixeira died,

1 It is evident that the quotations from Teixeira in "Hobson-Jobson" were made by Dr. Burnell, all being translations from the original Spanish. Dr. Burnell includes Teixeira's work in his " Tentative List of Books and some MSS. relating to the History of the Portuguese in India Proper." Mr. Albert Gray, in his translation of Pyrard (Hakluyt Society), vol. ii, part 1, p. 242, note, also refers to the Relacunes. The late Mr. P. A. Tiele, in his "Mémoire Bibliographique sur les Journaux des Navigateurs Néerlandais" (p. 255, note), says that the additional matter relating to Persia, Ormuz, ete., inserted after Hendrick Hagenaer's travels in Commelin's collection, was probably compiled by Commelin, chiefly from Teixeira's work, the title of which he quotes.

2 Dr. Kayserling refers to the fact that there were several noted men of this same name; and this is also pointed out in a footnote on p. 59 of the "Viaje del capitán Pedro Teixeira aguas arriba del rio de las Amazonas (1638-1639)," by Mancos Jimenez de la Espada (Madrid, 1889); but, in spite of this, the British Museum Library Catalogue enters this last book with the works of our author. 
but thinks Barbosa Machado, who says that Teixeira remained in Antwerp until his deatb, more worthy of credence. In his "Biblioteca Española-Portugueza-Judaica" (1890), however, Dr. Kayserling leaves the matter an open question.

From the many digressions made by Teixeira in his histories of Persia and Ormuz, it is evident that he had for a number of years travelled in the East, and was a keen observer. In many cases, where he relates facts that came under his own observation, he mentions no date; but I have picked out those passages where dates are given, and the result is as follows:-In lib. $i$, cap. xxxiii, he refers to a great inundation of the sea that took place along the north-west coast of Ceylon in 1585 ; but he does not say where he himself was at the time. The first date that he gives in connection with his own travels is 1587. This occurs in cap. xxix, lib. $i$, where, after referring to the "vast Plenty of Fish" in "the Bay of Mascate," he relates an incident that "hapned to me in that very Bay, in the year 1587, when coming thither with Ships of War, . . . ." A reference to De Couto's Dec. x, part ii, shows us how our author must have come to Muscat. In liv. viii, cap. $x$, of De Couto's work, we are told of the dispatch from Goa to Melinde (in' reply to a request from the king of that place) of a fleet under the command of Martim Affonso de Mello, the object of which was to punish the King of Mombasa and other native rulers who were intriguing with the Turks. This fleet sailed from Goa on January 9, 1587 ; and in the first chapter of liv. ix we are given details of the punishment inflicted on the intriguers. In cap. ii we are told of the arrival at Mombasa, in a sorely shattered condition, of the ship "Salvador," one of the fleet, under D. Jeronymo Coutinho, which had left Lisbon in March, 1586. This vessel having a valuable cargo on board, Martim Affonso resolved to try to bring it to Ormuz (and succeeded in doing so). The fleet, having sailed from Melinde (when, is not stated), called at the aguada de Teive (watering-place of Teive), which, apparently, was the Portuguese name 
for some point off Muscat. Thence the ships left for Ormuz; and, after a few days' stay, sailed for the estreito (Strait of Ormuz); but, on arriving at Kishm, Martim Affonso became so ill that the fleet returned to Ormuz, where the commander died and was buried. The fleet remained in the strait until September, when it returned to Ormuz, and under the command of Simão da Costa, Martim Affonso's father-in-law, sailed for Goa, where it arrived in October, 1587. One of the objects of the abovementioned expedition was the erection of a fortress at Muscat, which work was intrusted to Belchior Calaça, chief engineer, and captain of one of the vessels, who, after consulting with the Captain of Ormuz, left this place for Muscat, and accomplished his task. I have given these details, as they serve to throw some light on Pedro Teixeira's movements, regarding which he gives us only the solitary fact I have quoted. Whether he came from Portugal in the unfortunate "Salvador," or whether he was already in India, and accompanied the punitive expedition under Affonso de Mello, we have nothing to show. From his language, it seems more probable that he was with the whole fleet when he. visited Muscat, than that he accompanied Belchior Calaça thither from Ormuz. It seems also certain that he returned to Goa with the fleet in October, 1587, judging from what he tells us in connection with his next datum.

In cap. xxii of the same book he says (I quote Stevens's translation here and elsewhere):- "When I came from the Island of Ceylon, for Goa, in the Year 1588, with one that was presently after Viceroy of India, our Fleet came to an Anchor off of Barcelor, being desirous to see that Portuguese Fortress, and the City of the same Name, which they call, the upper Barcelor, Capital of Canara, and the Kingdom of the Chatins, above spoken of, I got leave to go a shore, . . . This was at the latter end of March, . . . ." How and when he came to Ceylon does not appear, nor whether he made any stay in the island at this time. (That he did stay in Ceylon on one 
occasion at least, we know from his own statement.) The person whom he accompanied from Ceylon to Goa, "that was presently after Viceroy of India" (or rather Governor), was Manoel de Sousa Coutinho, who, as we learn from De Couto (Dec. x, liv. x, cap. xiv), had been despatched by the Viceroy from Goa on February 4 with a fleet for the relief of Colombo, which had been enduring a prolonged siege at the hands of "Rajú" (Rāja Sinha I). The siege having been raised, and the enemy's forces having been driven back with great loss, Manoel de Sousa Coutinho sailed for Goa, calling at Cocbin, and visiting the fortresses of Cananore and Canara (the latter including Barcelor, referred to by Teixeira). He arrived at Goa at the end of March, and was received in great style by the citizens and the Viceroy, Dom Duarte de Menezes. Pedro Teixeira must have been an eye-witness of all these grand doings; but he is strangely silent on the subject. Dom Duarte de Menezes dying soon afterwards (on May 4, 1588), Manoel de Sousa Coutinho succeeded him as Governor; Mathias de Albuquerque, who was the first in succession, having left for Portugal the previous year.

In cap. xxix Teixeira refers to an incident that occurred "in the Year 1590, when John Correa Brito was Governor of the Fortress of Columbo, in Ceylon"; but again does not state where he himself was. In cap. xxxiii, however, he gives us another definite statement. Referring to the virtue of the "Porcupine Stone," he says:- - Of this I am an Eye Witness, having seen the Effects of it in several Places, at sundry times, and particularly at the City of Cochim, in the Years 1590, and 1591, where the Governor that then was, spent Two Porcupines Stones he had, in the Service of the poor, and needy, doing wonders against a Disease more dangerous and violent than the Plague, which reign'd Two whole Years, and carry'd off People in Four or Five Hours. This Distemper was a Cholerica Passio, by the Indians call'd Moxxy, and by the Portugueses Mordexim, ${ }^{1}$ being a Sort of Colick."

1 Cf. "Hobson-Jobson," s.v. 'Mort-de-chien.' 
In cap. $v i$ of the same book Teixeira speaks of a monstrous piece of ambergris found on the Zanzibar coast, near the town of Brava, in 1593; and in his "Breve Relacion de las Provincias . . . . de la Persia" he mentions a terrible earthquake that occurred in the city of Lar in September of the same year; but in neither case does he specify where he was. The same remark applies to cap. xxi, lib. $i$, where he describes a rebellion that took place in "the Province of Gueylon" in 1593 and 1594. In the same chapter, speaking of "the Five Governments the Province of Gueylon is divided into," he says: "The First is call'd Raxt, a Name taken from its chief City, which in the Year 1595, when I writ this [quando esto iua escrivêdo], was in the Possession of Iamshced Khan." From what he says in his Preface, it is evident that Teixeira was then residing in Ormuz. In cap. xxii he tells us that he was at Ormuz in 1596, and in his "brief account" of that kingdom he repeats the statement. In cap. xiv, referring to the "City of Mazandaron . . . seated . . . . near the Caspian Sea," he says: "In the Year 1597, when I was that way," etc. That he set out on a journey back (?) to India soon afterwards, we find from cap. xxix, where he says: "In the Year 1597, going from Goa to Malaca, ${ }^{1}$ we had extraordinary calms at Sea, and I being desirous to see a small Island, lying opposite to us, call'd Pulo Jarra, that is, Jarra Island, went ashore, . . . . At Malacea he seems to have remained for the next three years, for in the next chapter he says:- "When Francis Silva de Menpses was Governor of Malaca, he sent Don Francis Tello de Menezes Governor of the Philippine Islands, Presents, and among other Things was a small young Elephant, with his Comaca, being the Indian that managed him. This Elephant feeding about in the Island of Manila, was thirsty, and went away to the River of Paranaque, which was hard by to drink. [A crocodile seized the elephant, but got the worst of it.]

1 Apparently with the fleet under the enmmand of Lourenço de Brito, which left Goa on September 24, 1597, for Malacea, on receipt of the rumour of an intended attack by the Dutch on that place. (See De Couto, Dec. xii, liv. i, caps, vii and xii.) 
I was my self in June 1600 , at the very Place, on the River Paranaque, where this had hapned, but a few Days before." This was when Teixeira was on his journey home by way of America, as related in the first chapter of his "Viaje de la India hasta Italia." He there states that he left Malacea on May 1, 1600, in a small vessel sent "by the Commander Martin Alfonso de Melo's Order, to acquaint the Governor of those Islands [Philippines] with the coming of the Dutch into the Indian Seas."

With what object Pedro Teixeira undertook his various travels, we can only surmise; but, judging from his statement, quoted above, regarding the epidemic of cholera at Cochin, and the frequent medical references in his book, I cannot help thinking that he was a physician by profession. His observations are often valuable; ${ }^{1}$ and a reprint of Stevens's translation, competently edited, might deserve the attention of the Hakluyt Society.

There are a few errors in Mr. Sinclair's summary of Teixeira's journey, but a very serious one in the penultimate paragraph of his letter. This runs: "In one passage, in chapter vi of the 'Voyage,' he refers to 'the relation that I have made of the religious customs of the African races'; apparently a lost treatise." Here Mr. Sinclair has strangely misread Teixeira, who, in the passage in question, refers by name to (Giovanni) Botero, regarding whom and his works see the "Nouvelle Biographie Générale," tome vi.

\section{5, Bedford Place, Croydon. July 24, 1897.}

Donald Ferguson.

\footnotetext{
1 His derivations of words and names are, as might be expected, sometimes amusingly incorrect. For instance, he speaks of "Coromandel, or Coro Bandel, signifying the Port of Rice, berause of the great Quantities shipp'd off there for other Ports." Yule quotes this in his "Hobson-Jobson" (p. 198), and says: " He apparently compounds (Hind.) chaul 'cooked rice' (!) and bandel, i.e. bandar (qq.v.) 'harbour.' This is a very good type of the way etymologies are made by some people, and then confidently repeated." I think that it was not Hind. chanl, but Tamil corrw (boiled rice), that Teixeira had in his mind. Similarly absurd is De Couto's explanation of "Batecalou " (Batticaloa) as " the kingdom of rice."
} 